DOI: $10.1515 / \mathrm{abcsj}-2017-0014$

\title{
Soviet History as Crime Scene
}

Tom Rob Smith, Child 44 (London: Simon \& Schuster, 2008, 484 pp. ISBN 13:978-0857204080)

William Ryan, The Holy Thief (London: Mantle, 2010. 320 pp. ISBN 13:978-1447270133)

Sam Eastland, Berlin Red (London: Faber \& Faber, 2016. 384 pp. ISBN 13:978-0571322367)

In the centenary year of Russia's revolutions of 1917, when the postSoviet Russian state seems unable to articulate its relation to its own history, the historical crime that bases itself within Soviet history forces us, as readers, to consider what we know, what we think we know, and what we are able to entertain in order to enjoy a crime novel. William Ryan's The Holy Thief (2010), Sam Eastland's Berlin Red (2016), and Tom Rob Smith's Child 44 (2008) give us different perspectives of a Soviet society as background for the crime narrative to unfold. Quite what we make of their readings, and, more importantly, re-writings or reimaginings of a Soviet history depends on that old adage of the suspension of disbelief to differing degrees. Just where does acceptance of an historical narrative stop and incredulity start. This is no mean feat that each writer has to negotiate if we are to indulge in the pleasure of reading a good crime novel.

To be sure, we are confronted with a contentious history. We, as reader, must ask ourselves to what extent is the author complicit in a specific viewpoint or reading of history and, therefore, a re-writing of history. In the re-writing of Soviet history, and particularly that of the accepted narrative that has been handed down as 'barbaric', 'totalitarian', 'authoritarian', 'state terror', where does the writer stand who chooses to base the crime genre in such a loaded and contested space. From the present day perspective of the centenary of the revolutions of 1917, and specifically the Bolshevik October/ November revolution, we must ask whether there is a problematisation of history or just an acceptance of the 
'grand narrative'.

Clear examples might take us further in this. Sam Eastland's characterisation of Stalin in his Inspector Pekala series of novels, widely seem by accepted history as a mass-murderer, humanises the persona that is generally perceived to be a tyrant. Eastland goes against Marxist history by turning history itself into a personal narrative. History is individualised in the character of Inspector Pekala whose own personal narrative is represented as a symbolic, or metaphorical, reading of late Tzarist and early Stalin, post Lenin, era of Soviet history.

In Child 44 Tom Rob Smith's detective, Leo Demidov of the MGB the State Security Service, highlights the difficulty of attempting to write a narrative that is simply not permitted. The crime that Demidov seeks to define it is not recognised to exist by the state. Demidov is pushed towards the role of perpetrator as he seeks to solve the crime, writing a history that is not wanted. Smith highlights the problem of creating a narrative against the flow of what is accepted narrative by posing the question of how a crime that is not recognised by the state be deemed to have taken place. This places the narrative against the flow of the state's own writing of itself.

Crime fiction, to greater or lesser extent, is about the plausible narrative. Just how far can the reader's belief be stretched? Sam Eastland's Inspector Pekala fictions operate at the limit of the reader's belief. How credible is Pekala? With each successive novel his story becomes less credible and the suspension of disbelief more tenuous. By the latest novel, Berlin Red, Pekala is surreptitiously making his way into Berlin at the very end of WW2. His story has moved from personal detective to Tzar Nicholas II, then to Stalin, and now to pawn in the embryonic Cold War. The reader might begin to wonder about Pekala's age and constitution in this novel.

William Ryan, by keeping close to the police procedural, albeit against an apparently well researched 1930's Soviet context, provides a more convincing narrative. In common with Tom Rob Smith, Ryan's detective, Alexi Dmitriyevich Korelev, a criminal investigator with the Moscow Militia, in The Holy Thief is himself the subject of surveillance, pushed towards the role of criminal by the NKVD interest in his investigation.

These writers share in their fictional re-construction of history, of 
'the past'. A past that never existed. Eastland is, perhaps the most obvious, as he positions Inspector Pekala into the Stalin milieu. Ryan and Smith are no different, although their contexts, perhaps, require less suspension of disbelief. The past that each deals with never existed, being neither a memory nor a fact. Each also shares in the use of the wellestablished trope of the individual pitted against the state which, in this case, is the Soviet collective. We should ask ourselves if there is a romanticisation or fetishisation of dictatorship. Has a historical distancing enabled the tension between objective and subjective history to become blurred, enabling history to be seen only through the eyes of the Inspector? Here we ask where does history stop and fiction begin.

Clearly there is a safety in history. Closure has already happened. The reader knows what happened in the bigger narrative. Only within the fiction of the novel's plot itself lies the unresolved. Does this mean that Eastland, Ryan, and Smith take comfort in the known? Are each guilty of cultural voyeurism? Is the past there to be plundered? To what extent is the background of Soviet history the plot itself? What each of these writers share is the understanding, either explicit or implicit, that history is as much narrative and is re-created in its very re-writing as their fictions. Eastland, Smith and Ryan, whilst setting their narratives against the similar terrain of Soviet history, construct an imaginary past. Whilst the handed-down narrative of Soviet history is one where the focus of attention is on the collective rather than the individual, they each foreground the individual. Inevitably these two writings of history will collide, and this is where entertaining and engaging fiction is made.

STUART HUNT, University of Bristol 